University of Nebraska - Lincoln

DigitalCommons@University of Nebraska - Lincoln

Faculty Publications from the Harold W. Manter Laboratory of Parasitology

2004

\title{
Cardicola forsteri (Digenea: Sanguinicolidae) from the Heart of a Northern Bluefin Tuna, Thunnus thynnus (Scombridae), in the Northwest Atlantic Ocean
}

\author{
Stephen A. Bullard \\ Auburn University, ash.bullard@auburn.edu \\ Robert J. Goldstein \\ Robert J. Goldstein and Associates Incorporated, rgoldstein@rjgacarolina.com \\ Robert H. Goodwin III \\ captrg@msn.com \\ Robin M. Overstreet \\ Gulf Coast Research Laboratory, robin.overstreet@usm.edu
}

Follow this and additional works at: https://digitalcommons.unl.edu/parasitologyfacpubs

Part of the Parasitology Commons

Bullard, Stephen A.; Goldstein, Robert J.; Goodwin, Robert H. III; and Overstreet, Robin M., "Cardicola forsteri (Digenea: Sanguinicolidae) from the Heart of a Northern Bluefin Tuna, Thunnus thynnus (Scombridae), in the Northwest Atlantic Ocean" (2004). Faculty Publications from the Harold W. Manter Laboratory of Parasitology. 419.

https://digitalcommons.unl.edu/parasitologyfacpubs/419

This Article is brought to you for free and open access by the Parasitology, Harold W. Manter Laboratory of at DigitalCommons@University of Nebraska - Lincoln. It has been accepted for inclusion in Faculty Publications from the Harold W. Manter Laboratory of Parasitology by an authorized administrator of DigitalCommons@University of Nebraska - Lincoln. 
Comp. Parasitol.

71(2), 2004, pp. 245-246

\title{
Research Note
}

\section{Cardicola forsteri (Digenea: Sanguinicolidae) from the Heart of a Northern Bluefin Tuna, Thunnus thynnus (Scombridae), in the Northwest Atlantic Ocean}

\author{
Stephen A. Bullard, ${ }^{1,4}$ Robert J. Goldstein, ${ }^{2}$ Robert H. Goodwin III, ${ }^{3}$ \\ AND ROBIN M. OVERSTREET ${ }^{1}$ \\ ${ }^{1}$ Gulf Coast Research Laboratory, The University of Southern Mississippi, P.O. Box 7000, Ocean Springs, \\ Mississippi 39566, U.S.A. (e-mail: robin.overstreet@usm.edu), \\ ${ }^{2}$ Robert J. Goldstein and Associates Incorporated, Durant Road Office Park, 8480 Garvey Drive, Raleigh, \\ North Carolina 27616, U.S.A. (e-mail: rgoldstein@rjgacarolina.com), and \\ ${ }^{3} 825$ West Main Street, Hyannis, Massachusetts 02601, U.S.A. (e-mail: captrg@msn.com)
}

ABSTRACT: We report a specimen of Cardicola forsteri Cribb, Daintith, and Munday, 2000 (Digenea: Sanguinicolidae) from the lumen of the heart of a northern bluefin tuna, Thunnus thynnus (Linnaeus, 1758) (Scombridae), that was $218 \mathrm{~cm}$ in total length (TL) and caught in the northwest Atlantic Ocean $12 \mathrm{~km}$ south of Cape Lookout, North Carolina. The hearts of 12 similarly sized northern bluefin tuna (127-262 cm TL) from George's Bank, northwest Atlantic Ocean, were not infected. This is the first report of C. forsteri from a wild host and of a sanguinicolid from any scombrid in the northwest Atlantic Ocean. Bluefin tuna is cultured in sea cages because of its highly prized flesh, and the fact that a blood fluke infects this host is significant because some blood flukes have been identified as serious pathogens of cage-cultured fish.

KEY WORDS: Cardicola forsteri, Sanguinicolidae, Digenea, blood fluke, Thunnus thynnus, northern bluefin tuna, Scombridae, heart, northwest Atlantic Ocean, cage, aquaculture, disease.

The northern bluefin tuna, Thunnus thynnus (Linnaeus, 1758) (Scombridae), is one of the largest and most sought after teleosts, with individuals reaching $3.2 \mathrm{~m}$ in total length (TL) and $680 \mathrm{~kg}$ in weight and being purchased for as much as US $\$ 80,000$ in the Japanese sushi and sashimi market (Kantor, 1996). The capture fishery for northern bluefin tuna is commercially lucrative and provides most of the bluefin tuna purchased. However, cage culture operations that maintain tunas in the southwest Pacific Ocean and Mediterranean Sea supplement the high demand. For cage systems, small wild tuna in schools are purseseined and transferred to a floating net cage that is towed to a farm site where the fish are fattened before harvest and sale (Fish Farming International, February 2003; Apeitos, personal communication).

\footnotetext{
${ }^{4}$ Corresponding author (e-mail: ash.bullard@usm.edu).
}

Tuna aquaculture is presently in its early stages of development and will likely continue to expand, but with this expansion, parasitic disease will become increasingly important. Blood flukes (Sanguinicolidae) infect the vascular system and body cavity of marine and freshwater fish throughout the world (Smith, 1997a, b), and under appropriate conditions, some are serious pathogens of cage-cultured fish (Hoffman et al., 1985; Ogawa et al., 1989; Ogawa and Fukudome, 1994; Munday and Hallegraeff, 1998; Bullard and Overstreet, 2002). The disease caused by some blood flukes, sanguinicoliasis, primarily results from a large number of fluke eggs sequestered in the afferent brachial arteries and may asphyxiate the host. Information on the host range and geographic distribution of tuna blood flukes is relevant to the tuna aquaculture industry because it could help aquaculture managers identify infections or prevent sanguinicoliasis (Bullard and Overstreet, 2002). In this study, we extend the host and geographic range of a potentially pathogenic blood fluke that infects 2 commercially valuable tunas.

Specimens of the northern bluefin tuna were captured by hook and line and killed by severing the spinal cord. In the field, the heart was excised, placed in a sample bag, bisected, doused with near-boiling water, and fixed in $70 \%$ ethanol (EtOH) or 5-10\% neutral buffered formalin. In the laboratory, the contents of the bag were examined with the aid of a dissecting microscope. The worm was stained in Van Cleave hematoxylin with several additional drops of Ehrlich hematoxylin, made basic in $70 \% \mathrm{EtOH}$ with lithium carbonate and butylamine, dehydrated, cleared in clove oil, and mounted in Canada balsam (Bullard and Overstreet, 2003). The specimen was deposited in the United States National Parasite Collection (USNPC), 
United States Department of Agriculture, Beltsville, Maryland (USNPC 94131).

A single specimen of Cardicola forsteri Cribb, Daintith, and Munday, 2000, was collected from the lumen of the heart of a northern bluefin tuna, $T$. thynnus, that was $218 \mathrm{~cm}$ in TL and captured in the northwest Atlantic Ocean $12 \mathrm{~km}$ south of Cape Lookout, North Carolina. The hearts of 12 similarly sized northern bluefin tuna (127-262 cm TL) from George's Bank, northwest Atlantic Ocean, were also examined, but none were infected. Previously, this fluke only has been reported from the heart of caged southern bluefin tuna, Thynnus maccoyii (Castelnau, 1872), from south Australia (Cribb et al., 2000; Colquitt et al., 2001). This is the first report of $C$. forsteri from a wild host and from the northern hemisphere and constitutes the only known sanguinicolid from any scombrid in the northwest Atlantic Ocean. Two other sanguinicolids have been described from scombrids: Cardicola congruenta Lebedev and Mamaev, 1968, from the branchial vessels of the kawakawa, Euthynnus affinis (Cantor, 1849), in the Gulf of Tonkin, South China Sea, and Cardicola ahi Yamaguti, 1970, from the gills of both the yellowfin tuna, Thunnus albacares (Bonnaterre, 1788) (as Euthynnus macropterus), and the bigeye tuna, Thunnus obesus (Lowe, 1839) (as Parathunnus sibi), in the North Pacific Ocean off Hawaii (Smith, 1997b).

The seemingly disjunct distribution of $C$. forsteri is noteworthy. The life cycle of $C$. forsteri is unknown, but if it follows that of all studied sanguinicolids, then it would include a single snail, bivalve, or polychaete intermediate host species (Køie, 1982; Smith, 1997a). If so, the unidentified intermediate host may be widespread, occurring within the range of each of the fish hosts. On the other hand, the infected individual bluefin tuna could have migrated from southern oceans.

This study was supported by National Marine Fisheries Service, U.S. Gulf of Mexico Marine Stock Enhancement Program (US-GMSEP) Award No. NA06FL0501.

\section{LITERATURE CITED}

Bullard, S. A., and R. M. Overstreet. 2002. Potential pathological effects of blood flukes (Digenea: Sanguinicolidae) on pen-reared marine fishes. Proceedings of the 53rd Gulf and Caribbean Fisheries Institute 53: $10-25$.
Bullard, S. A., and R. M. Overstreet. 2003. Elaphrobates euzeti gen. and sp. n. (Digenea : Sanguinicolidae) from snappers (Lutjanidae) in the Gulf of Mexico. In Taxonomie, écologie et évolution des métazoaires parasites. Pages 97-113 in C. Combes and J. Jourdane, eds. Taxonomy, Ecology and Evolution of Metazoan Parasites. (Livre hommage à Louis Euzet). Tome 1. Presses Universitaires de Perpignan, Perpignan, France.

Colquitt, S. E., B. L. Munday, and M. Daintith. 2001. Pathological findings in southern bluefin tuna, Thunnus maccoyii (Castelnau), infected with Cardicola forsteri (Cribb, Daintith \& Munday, 2000) (Digenea: Sanguinicolidae), a blood fluke. Journal of Fish Diseases 24:225-229.

Cribb, T. H., M. Daintith, and B. Munday. 2000. A new blood-fluke, Cardicola forsteri, (Digenea: Sanguinicolidae) of southern blue-fin tuna (Thunnus maccoyii) in aquaculture. Transactions of the Royal Society of South Australia 124:117-120.

Hoffman, G. L., B. Freid, and J. E. Harvey. 1985. Sanguinicola fontinalis sp. nov. (Digenea: Sanguinicolidae): a blood parasite of brook trout, Salvelinus fontinalis (Mitchill), and longnose dace, Rhinichthys cataractae (Valenciennes). Journal of Fish Diseases 8:529-538.

Kantor, M. 1996. Historic rationale, effectiveness, and biological efficiency of existing regulations for the U.S. Atlantic bluefin tuna fisheries: a report to the U.S. Congress. Final report for section 310 of Public Law 104-43, The Fisheries Act of 1995. National Marine Fisheries Service, Silver Spring, Maryland.

Køie, M. 1982. The redia, cercaria and early stages of Aporocotyle simplex Odhner, 1900 (Sanguinicolidae)a digenetic trematode which has a polycheate anneli$\mathrm{d}$ as the only intermediate host. Ophelia 21:115-145.

Munday, B. L., and G. M. Hallegraeff. 1998. Mass mortality of captive southern bluefin tuna (Thunnus maccoyii) in April/May 1996 in Boston Bay, South Australia: a complex diagnostic problem. Fish Pathology 33:343-350.

Ogawa, K., and M. Fukudome. 1994. Mass mortality caused by blood fluke (Paradeontacylix) among amberjack (Seriola dumerili) imported to Japan. Fish Pathology 29:265-269.

Ogawa, K., K. Hattori, K. Hatai, and S. Kubota. 1989. Histopathology of cultured marine fish, Seriola purpurascens (Carangidae) infected with Paradeontacylix spp. (Trematoda: Sanguinicolidae) in its vascular system. Fish Pathology 24:75-81.

Smith, J. W. 1997a. The blood flukes (Digenea: Sanguinicolidae and Spirorchidae) of cold-blooded vertebrates: part 1. A review of the published literature since 1971, and bibliography. Helminthological Abstracts 66: 255-294.

Smith, J. W. 1997b. The blood flukes (Digenea: Sanguinicolidae and Spirorchidae) of cold-blooded vertebrates: part 2. Appendix I: comprehensive parasite-host list; Appendix II: comprehensive host-parasite list. Helminthological Abstracts 66:329-344. 